\title{
Erratum to: Safety and efficacy of an E2 glycoprotein subunit vaccine produced in mammalian cells to prevent experimental infection with bovine viral diarrhoea virus in cattle
}

\author{
Andrea Pecora $^{1}$ - María Sol Pérez Aguirreburualde ${ }^{1}$ Agustín Ostachuk $^{1}$. \\ Alejandra Aguirreburualde ${ }^{2}$ - Maria Rosa Leunda ${ }^{3}$ - Anselmo Odeon ${ }^{3}$. \\ Sebastián Chiavenna ${ }^{1}$ - Diego Bochoeyer ${ }^{2} \cdot$ Marcelo Spitteler $^{2} \cdot$ Jorge L. Filippi $^{2}$ • \\ Maria J. Dus Santos ${ }^{1}$ - Susana M. Levy ${ }^{2}$. Andrés Wigdorovitz ${ }^{1}$
}

Published online: 7 July 2016

(C) Springer Science+Business Media Dordrecht 2016

Erratum to: Vet Res Commun (2012) 36:157-164

DOI: 10.1007/s11259-012-9526-x

Agustín Ostachuk has been added to the list of authors. The affiliations have also been updated.

The online version of the original article can be found at http://dx.doi. org/10.1007/s11259-012-9526-x.

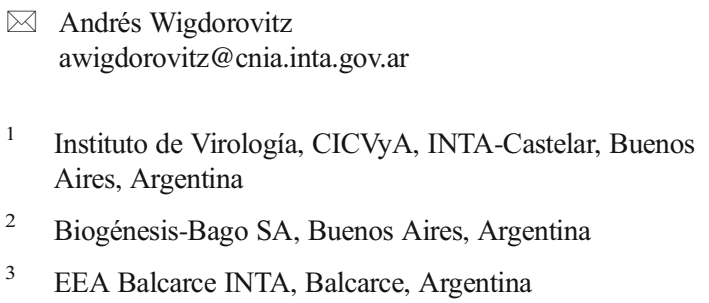

2 Biogénesis-Bago SA, Buenos Aires, Argentina

3 EEA Balcarce INTA, Balcarce, Argentina 